\title{
Modernization of Housing Estates Towards Sustainable Development: What do Housing Estate Managers Provide, What do the Users See?
}

\begin{abstract}
Anna Ostańska
Department of Architecture and Urban Planning, Faculty of Civil Engineering and Architecture, Lublin University of Technology, Nadbystrzycka 40, 20-618 Lublin, Poland, a.ostanska@ pollub.pl

Abstract. Modernizing multi-family residential estates in operation for about 40 years is a multifaceted and complex process. In Poland, these assets cannot be considered "degraded" yet, they are not an obvious object of deep retrofit actions. The literature on the subject and the author's own research confirm that the management of Polish housing estates is carried out with the focus on current repairs and improving energy efficiency by insulating the buildings' envelopes. Poland lacks long-term programs to implement retrofitting actions based on the analysis of both social and technical needs and aimed at improving the estate's sustainability parameters. The author puts forward an original approach to the programming of sustainable housing stock retrofit based on the PEARS model (PeopleEnvironment-Actions-Resources-Sociology). The paper focuses on the social research part of the model and presents the case-based analysis - the results of the recurring survey conducted to provide input for sustainable planning of the estate improvements. The paper is a summary of over ten years of research and studies on practices of maintenance of infrastructure and buildings, changing user needs, and user opinions on the possible directions towards sustainable housing.
\end{abstract}

Keywords: Housing Stock, Deep Retrofit, Sustainable Housing, Recurrent Survey.

\section{Introduction}

Polish housing estates with prefabricated buildings, created between nineteen-sixties and nineties, are still considered a valuable asset (Zyga, 2014). This is due to their generally satisfactory technical condition (Nowogońska, 2017), good location and presence of local amenities, as well as the shortage of affordable housing. However, the maintenance of these assets becomes a challenge because of the scale of the problem (Ostańska, 2019) (buildings of this type and age are present in practically all towns and cities, as shown in Fig. 1), complex ownership structure (obstacle in the decision-making process (Radziszewska-Zielina, 2006)), and changing regulations (promoting individual ownership of flats (Radziszewska-Zielina and Gleń, 2013, 2014). The growing expectations towards energy efficiency, user safety, and comfort, accompanied by growing requirements of the building codes, make the "prefab blocks" becoming obsolete. Therefore, keeping the buildings fit for purpose requires (Runkiewicz et al., 2014) not only repairs, but also investment (Yiu and Leung, 2005; Taczanowska and Ostańska, 2012; Radziszewska-Zielina and Gleń, 2013; Komar, 2014, Wójtowicz, 2014; Stevenson and Baborska-Narozny, 2017). She wrote about the types and needs of surveys in architecture, among others, about the types and needs of surveys in architecture Niezabitowska (2014).

The residents of the housing estates have the greatest knowledge on the functional deficiencies of the flats, the buildings, and the infrastructure and amenities of the estates. As flat owners, members of the housing cooperatives, or just clients-users, they have also the power 
to oppose the investment plans proposed by the estate management as well as the power to affect them. As observed in practice, the residents rarely use the opportunity of the latter, so they rarely participate in the management of the estates in an active way.

The aim of the research presented in this paper was twofold: to collect input for planning improvement measures customized for a particular estate directly from the users, and to stimulate the interest of the residents in the possibilities of influencing the managers' decisions, especially regarding the current needs and corrective or improvement actions aimed at "reviving" the estates (Ostańska, 2009, 2015).
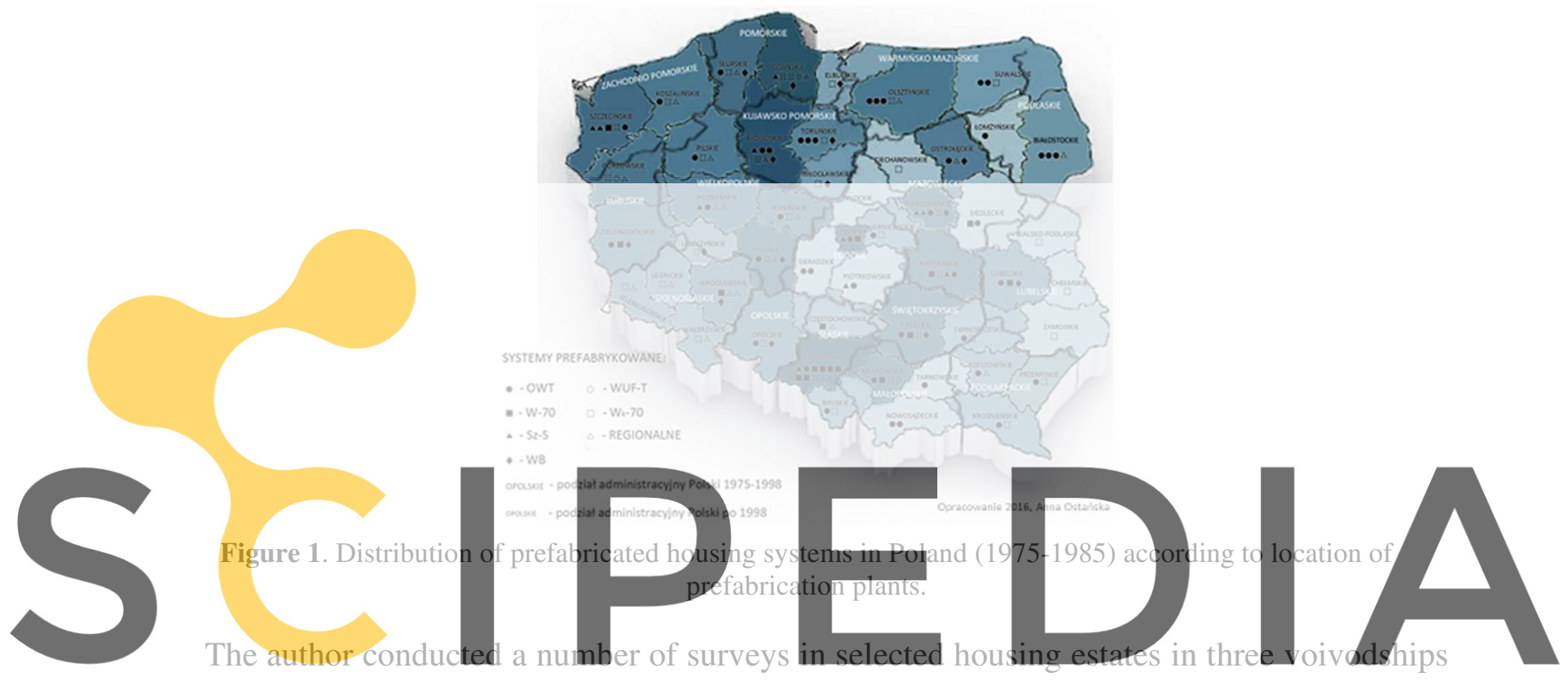

(Fig. 2). Most of them were carried out in Lubelskie Voivodship and repeated in regular

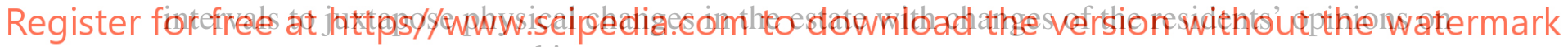
most urgent or most wanted improvements.

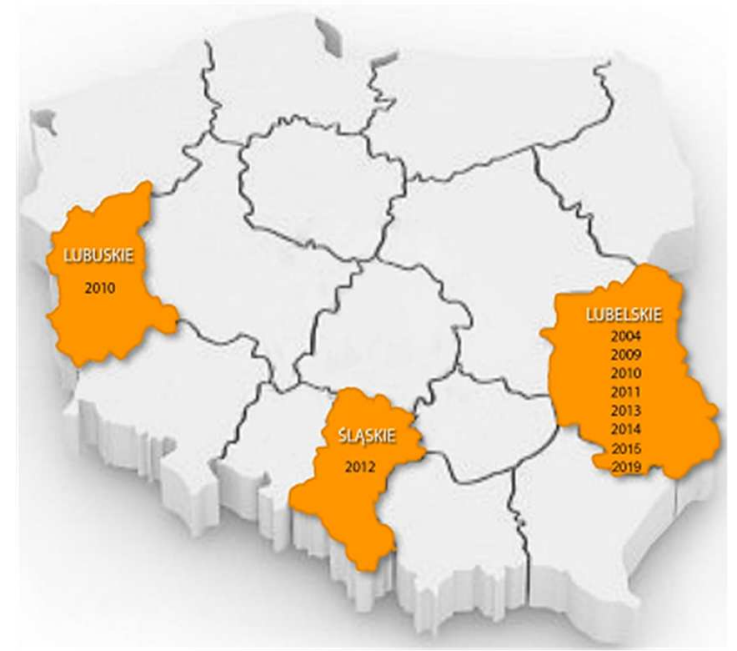

Figure 2. Location of surveys. 
The paper presents the methodology behind the research and discusses results obtained in three particular housing estates in Lubartów (Ostańska, 2018). The surveys consisted in a questionnaire-based direct interview with the residents conducted first in 2010, and repeated in 2014.

\section{Methods}

The idea of the survey is presented in Figure 3. Its starting point was the selection of the object of research: an estate. After obtaining the estate management's consent to conduct the survey, a preliminary "in situ" assessment of the condition of the buildings and infrastructure was conducted and clusters of buildings representative for the estate were selected to serve as the sample. The residents of these buildings were then approached at home to provide answers to a set of questions on both renovation $(R)$ and modernisation needs of the estate, the building and the flats. The modernisation comprises sustainability $(M e)$ and functional $(M f)$ aspects.

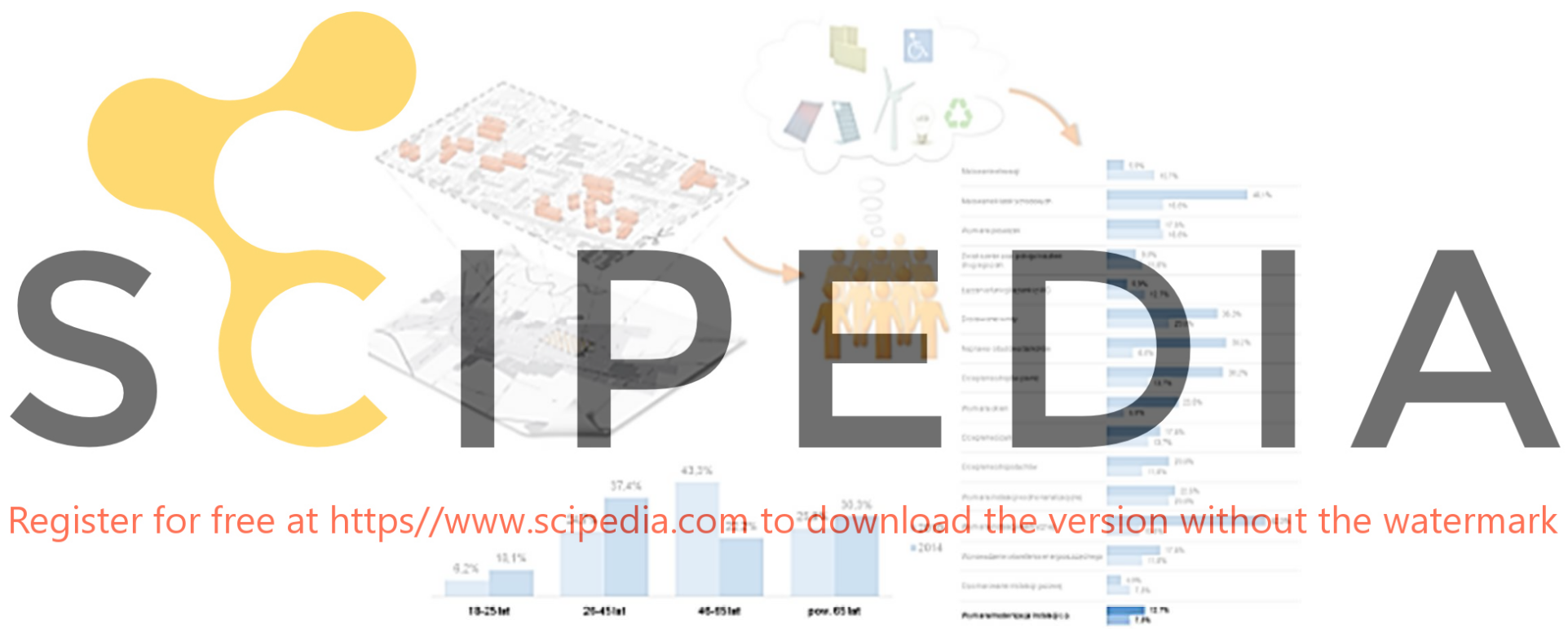

Figure 3. The idea of the survey on the opinions of the housing estate residents.

The interviews were intended to be repeated according to the same questionnaire in regular intervals. The purpose of repeating the survey was to update the insight into the modernization needs based on the opinion of the residents, and analyzing the perceived effects of the estate managers' activities.

The participants of the research were limited to adults living in the blocks of flats selected as the sample. Only one person per flat was asked to give answers.

The interviews were conducted on the basis of an original questionnaire: a standard form adjusted to the particularities of the housing estate in question. The questionnaire contained a total of 26 questions, including open-ended, closed-ended single-choice and closed-ended multiple-choice questions. Semi-open questions (logically open, technically closed) provided a list for multiple choice of feasible corrective actions, including measures for saving energy and improving functionality. Other semi-open questions concerned the list of common-use facilities 
present in the estate to check if they are still in use. A single logically and technically open question concerned the works the residents conducted on their own in their flats. The classification and demographic questions concerned: age, education, migration and participation in the costs of renovation.

Thus, the full scope of the survey questions comprised:

- deficiencies in local amenities,

- condition of the estate's infrastructure,

- comfort of living (buildings and dwellings),

- opinion on the priorities for corrective actions.

The complete questionnaire form can be found in Ostańska (2018) (Appendix 3a, Questionnaire C/2010).

\section{Results}

In the particular case presented in this paper, the survey was conducted twice to answer the following questions:

1) Did the residents" priorities on "the most urgent needs" change over time and with the measures actually taken in the estate?

2) Did the preferences of the housing estate residents' needs change in terms of repair/renovation works $(R)$, modernization measures aimed at environment protection $(M e)$, and functional modernization (Mf)?

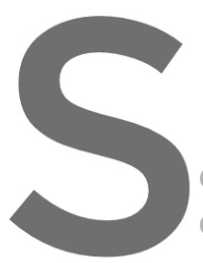

3) Did the housing cooperative's spending stay in proport residents?

The research conducted questionnaires in 2010 and 102 questionnaires estates in Lubartów significantly different $(\chi 2[3, n=196]=10.46 ; p=0.015 ; \phi=0.2$

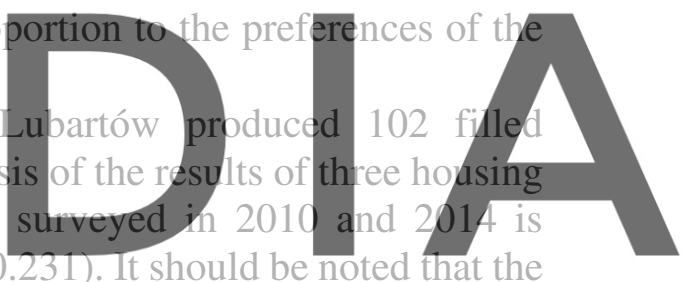
number of people aged over 65 slightly increased (25.8\% in 2010 vs. 30.3\% in 2014). However,

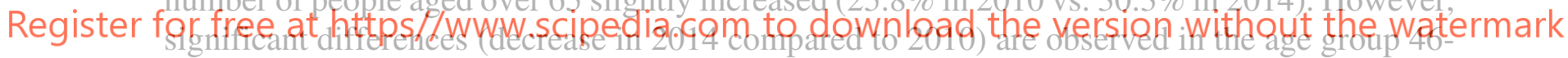

65. The remaining groups do not differ from each other in particular years (Figure 4).

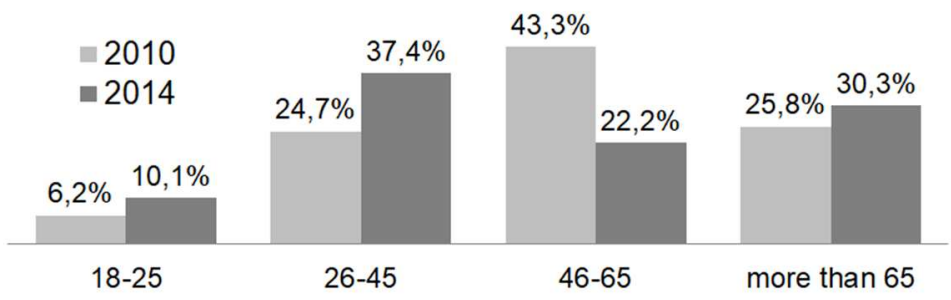

Figure 4. Age structure of the respondents: 2010 and 2014.

Considering the residents' responses to the perceived "most urgent needs" (Figure 5), it was observable that the average number of unsatisfied "most urgent needs" per respondent in 2014 (2.63) was lower than in $2010(3.95)(t(204)=2.96 ; \mathrm{p}=0.003)$. The detailed analyses confirmed differences in seven of the sixteen areas studied:

- $\quad$ Facade painting $(\chi 2[1, \mathrm{n}=204]=5.10 ; \mathrm{p}=0.024 ; \phi=0.158)$ - increase from $5.9 \%$ to $15.7 \%$, 
- Painting staircases $(\chi 2[1, \mathrm{n}=204]=19.02 ; \mathrm{p}<0.001 ; \phi=-0.305)-\mathrm{a}$ drop from $46.1 \%$ to $18.6 \%$,

- $\quad$ Installing a lift $(\chi 2[1, \mathrm{n}=204]=6.17 ; \mathrm{p}=0.013 ; \phi=-0.174)-\mathrm{a}$ drop from $36.3 \%$ to $20.6 \%$,

- $\quad$ Repair or replacement of balconies $(\chi 2[1, \mathrm{n}=204]=25.81 ; \mathrm{p}<0.001 ; \phi=-0.356)-\mathrm{a}$ drop from $39.2 \%$ to $20.6 \%$,

- Basement ceiling insulation $(\chi 2[1, \mathrm{n}=204]=15.93 ; \mathrm{p}<0.001 ; \phi=-0.279)-$ a drop from $38.2 \%$ to $13.7 \%$,

- Window replacement $(\chi 2[1, \mathrm{n}=204]=12.66 ; \mathrm{p}<0.001 ; \phi=-0.249)-$ a drop from $23.5 \%$ to $5.9 \%$,

- $\quad$ Replacement of electrical installation $(\chi 2[1, \mathrm{n}=204]=40.16 ; \mathrm{p}<0.001 ; \phi=-0.444)-$ a drop from $52.0 \%$ to $10.8 \%$.

No significant differences were noted in other aspects. Interestingly, only one aspect (facade painting) received a significant increase of residents' interest, almost by $10 \%$, in relation to the results obtained in the first study.

Modernizing/replacing heating system

Installing gas meters

Replacing the lighting system with an energy

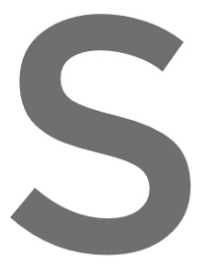

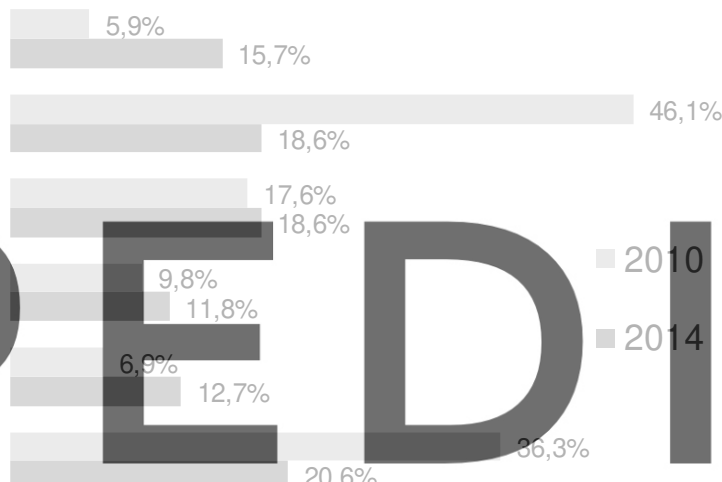

$20,6 \%$

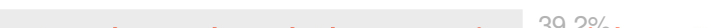

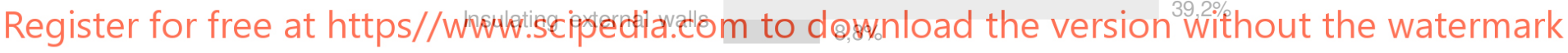

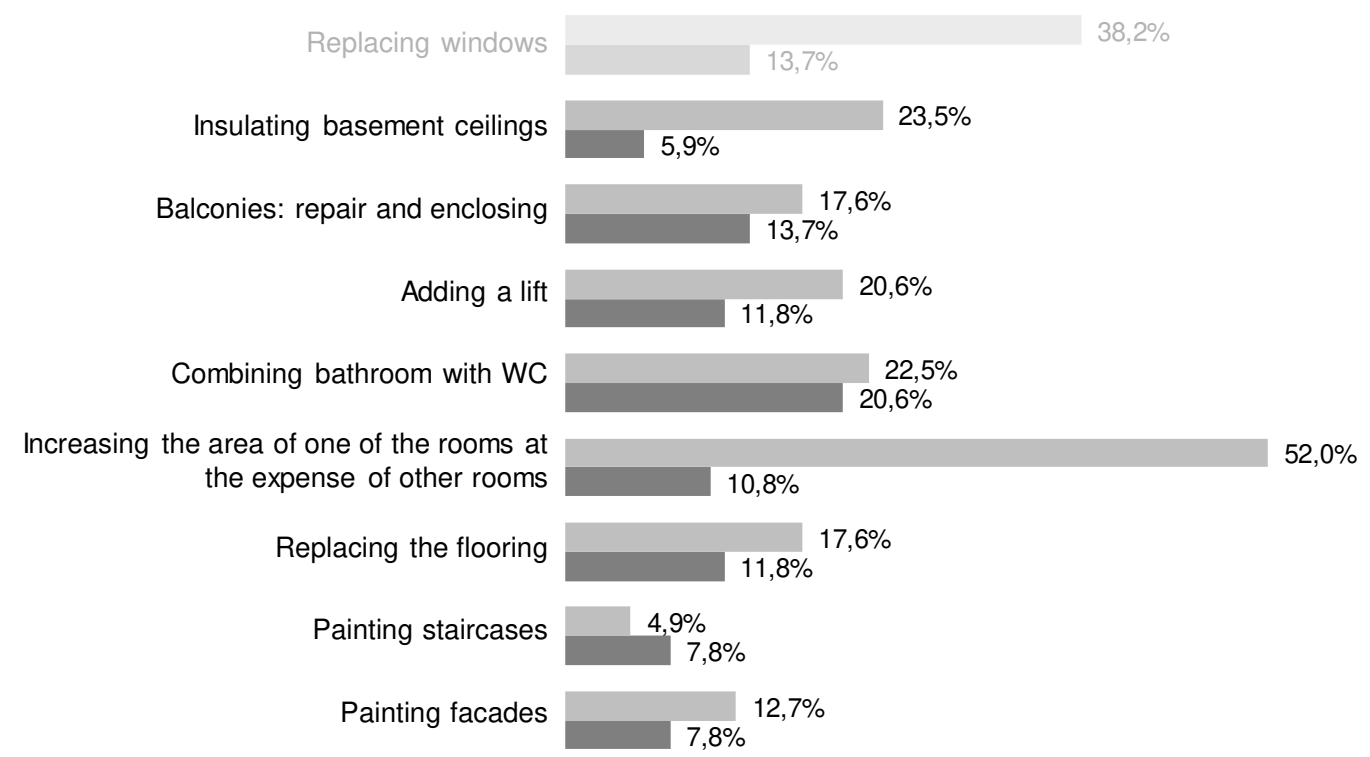

Figure 5. Priorities of improvements according to the respondents (share in the number of all indications). 
Comparing the results of 2010 and 2014 (Figure 6), differences were observed in the category of "modernization measures aimed at environment protection" $(\mathrm{Me})$ (decrease from $68.6 \%$ to $58.3 \% ; \mathrm{t}(204)=3.975 ; \mathrm{p}<0.001)$ and functional modernization $(M f)$ (increase from $16.7 \%$ to $30.3 \% ; \mathrm{t}(204)=-2.436 ; \mathrm{p}=0.016)$.

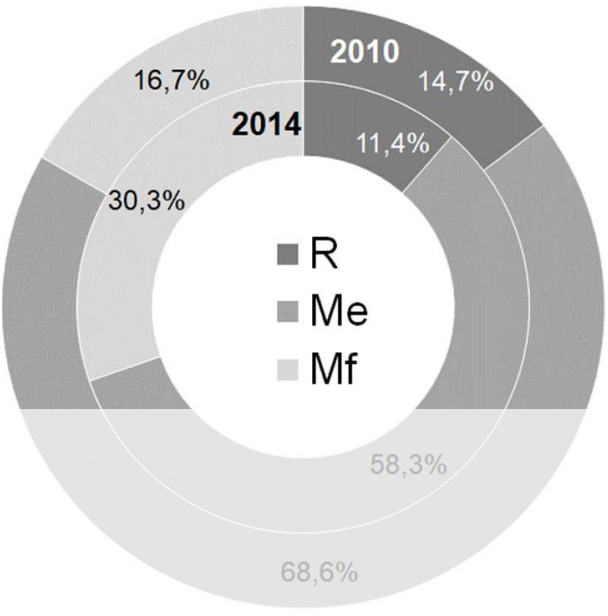

Figure 6. The residents' priorities of "most urgent" improvements according category and the year of the survey (description in the text).

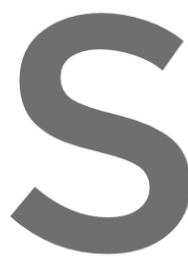

The next step was to the residents. This was activities $(R)$, moderniz (Me), and functional in indications of the most
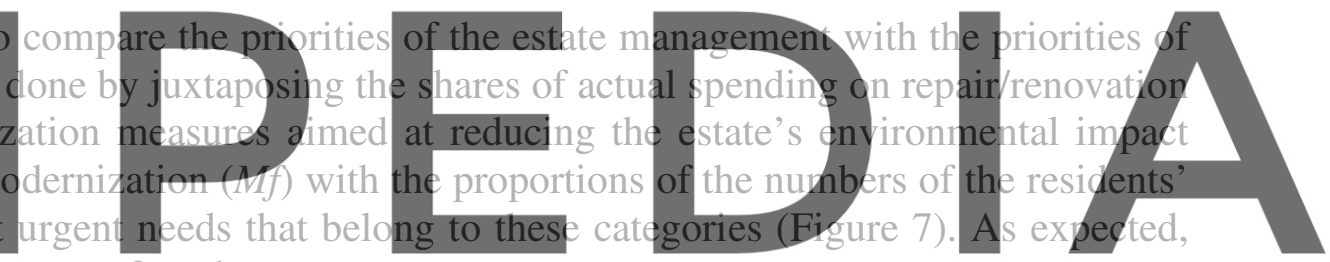

significant discrepancies were found.

Register for free at https//www.scipedia.com to download the version without the watermark
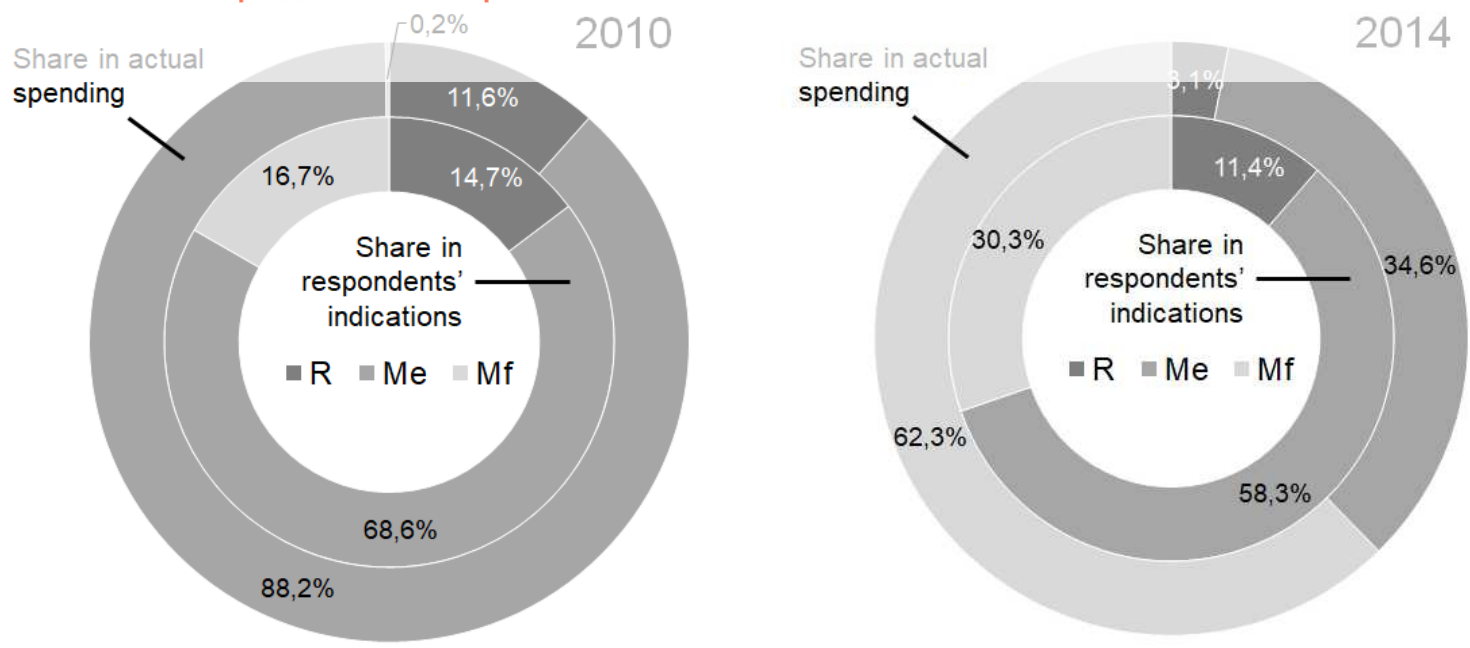

Figure 7. Users' perceived "most urgent" needs for improvements vs. actions taken by the estate managers expressed as the share in total spending (description in the text) 
In 2010, $68.6 \%$ of all residents' indications on the "most urgent needs" concerned $\mathrm{Me}$, whereas the housing cooperative spent $88.2 \%$ of its budget on actions within this category $(\mathrm{t}(211)=-7.544 ; \mathrm{p}<0.001)$. As for $M f$, the cooperative spent practically nothing, while $16.7 \%$ of the inhabitants pointed to the urgency of actions from this category $(\mathrm{t}(211)=7.000 ; \mathrm{p}<$ $0.001)$.

In 2014, current repairs consumed only $3.1 \%$ of the cooperative's budget, though the residents' indications on actions from this category were $11.4 \%$ of all indications. The $\mathrm{Me}$ related "most urgent" needs constituted $58.3 \%$ of all residents' indications, whereas the housing cooperative's spending on them constituted $34.6 \%$ of their total expenditures $(\mathrm{t}(102)=4.940 ; \mathrm{p}$ $<0.001)$. The "most urgent needs" in functional modernization had $30.3 \%$ of residents" indications, but the cooperative spent as much as $62.3 \%$ of the budget on this category $(\mathrm{t}(102)$ $=-6.666 ; \mathrm{p}<0.001)$. This was possible due to extra funds from an EU-sponsored urban regeneration grant.

\section{Summary and Conclusions}

The residents' opinions on "urgent needs" related with maintenance and improvements to the fabric of their housing estates evolve over time (between the first survey in 2010 and the next one in 2014) and with the measures actually taken by the estate management. In particular, the repair/renovation needs seemed to be at least partly satisfied, as less people pointed to the items from this category in the second survey. A similar number of items from the list of

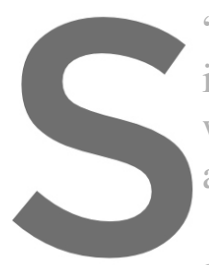
"modernization measures aimed at environment protection implementing in 2010 which may be related to accessibility.

The proportion between
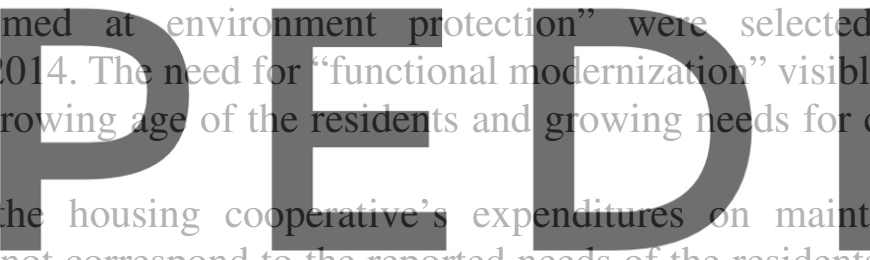

modernization measures does not correspond to the reported needs of the residents, especially in terms of functional modernization: in the case of the presented housing estate, no inyestment

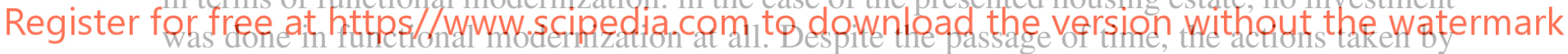

the estate management are not consistent with the expectations of the inhabitants.

The method of monitoring the residents' needs adopted in the presented research, so a direct interview, proved feasible. The results provide a valuable input on user expectations, and this input was successfully used in practice to define the scope of modernization projects in several housing estates in Lubartów. Keeping up to date with user needs, the housing estate managers are able to revise the action plans.

Though the face-to-face interview is a labor-intensive way of collecting input, both the cost and effort related with data collection and analysis proved acceptable. However, the surveys should be continued on a regular basis. To facilitate the dialog between the residents and the estate management and to streamline the data collection process in the future, it is advisable to construct an Internet platform. Its design is the current subject of the author's research.

\section{ORCID}

Anna Ostańska: http://orcid.org/ 0000-0002-1789-4288 


\section{References}

Komar, B. (2014). Wspótczesna jakość spótdzielczej przestrzeni osiedlowej w świetle zasad rozwoju zrównoważonego na wybranych przykładach [Quality of space of the cooperative housing estates in the light of the principles of sustainable development on the basis of selected examples]. Gliwice:Wydawnictwo Politechniki Śląskiej.

Niezabitowska, E.D. (2014). Metody $i$ techniki badawcze $w$ architekturze [Research methods and techniques in architecture]. Gliwice: Wydawnictwo Politechniki Śląskiej.

Nowogońska, B. (2017). Diagnoza w procesie starzenia budynków mieszkalnych wykonanych $w$ technologii tradycyjnej [Diagnosis in the process of aging of residential buildings erected using traditional methods]. Warszawa: Komitet Inżynierii Lądowej i Wodnej PAN.

Ostańska, A. (2009). Podstawy metodologii tworzenia programów rewitalizacji dużych osiedli mieszkaniowych wzniesionych w technologii uprzemysłowionej na przykładzie osiedla im. St. Moniuszki w Lublinie [Problems of revitalization of residential quarters of prefabricated buildings on the basis of Stanislaw Moiuszko Quarter in Lublin]. Lublin: Politechnika Lubelska.

Ostańska, A. (2015). Algorithm of revitalization programme design for housing estates, Civil and Environmental Engineering Reports, 18(3) 107-114

Ostańska, A.E. (2018). Programowanie rewitalizacji osiedli mieszkaniowych z zastosowaniem modelu PEARS [Programming regeneration of housing estates. Application of PEARS model]. Lublin: Komitet Inżynierii Lądowej i Wodnej PAN.

Ostańska A. (2019), Analiza wyników badań struktury zasobów mieszkaniowych w Polsce na przykładzie budynków wznoszonych w technologii prefabrykowanej [Analysis of the results of research on the structure of housing resources in Poland on the example of buildings erected in prefabricated technology] Przegląd Budowlany, nr 5, s. 41-43.

Radziszewska-Zielina, E. (2006). Metody badań marketingowych w budownictwie, podręcznik dla studentów wyższych szkót technicznych [Methods of marketing research in the construction industry, a handbook] Kraków: KNOW-HOW.

Radziszewska-Zielina, E. prefabrykatów [Oppoitun

Radziszewska-Zielina, mieszkaniowego z prefar
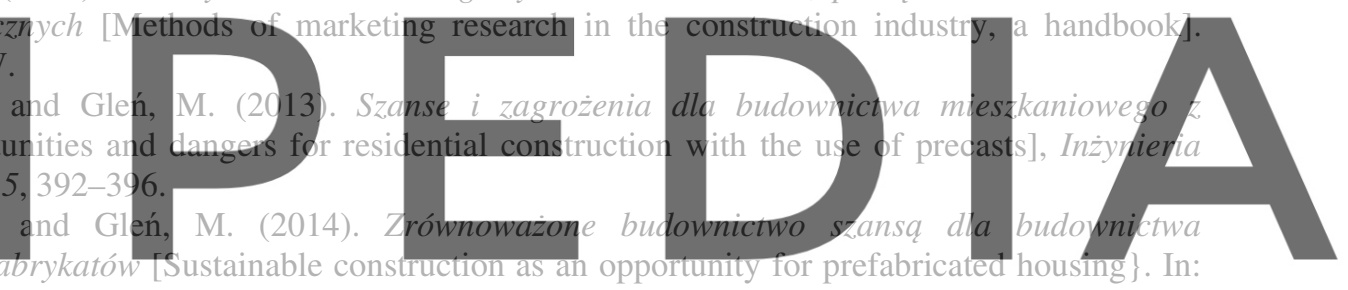

A. Sobocińska and M. Pisarski (Eds.), Wybrane zagadnienia z budownictwa ogólnego (pp. 195-210). Radom:

Register for fipeengt https//www.scipedia.com to download the version without the watermark

Radziszewska-Zielina, E. and Gleń, M. (2013). Conducting SWOT analysis in the field of housing construction using prefabricates. Economics and Business Management, 11(1-2), 36-42.

Runkiewicz, L., Szudrowicz, B., Prejzner, H., Geryło, R., Szulc, J. and Sieczkowski, J. (2014), Diagnostyka 1 modernizacja budynków wielkopłytowych (cz. 1) [Diagnostics and modernization of prefabricated concrete buildings (part 1)], Przegląd Budowlany, 7-8, 54-60.

Stevenson, F. and Baborska-Narozny M. (2017). Housing performance evaluation: challenges for international knowledge exchange. Building Research \& Information. 46(5), 501-512. doi: 10.1080/09613218.2017.1357095.

Taczanowska, T. and Ostańska, A. (2012). Dokładność realizacji a potrzeba modernizacji budynków wielkoptytowych [Assembly accuracy and the need to modernize large panel buildings], Warszawa: Medium.

Wójtowicz, M. (2014). Wielka ptyta - problem techniczny czy społeczny? [Buildings made of large panel elements - technical or social problem?] In: A. Halicka (Ed.) Budownictwo na obszarach zurbanizowanych: nauka, praktyka, perspektywy (pp. 329-340). Lublin: Politechnika Lubelska.

Yiu, C.Y. and Leung A.Y.T. (2005), A cost-and-benefit evaluation of housing rehabilitation, Structural Survey, 23(2), 138-151, https://doi.org/10.1108/02630800510593701.

Zyga, J. (2014). Ocena budownictwa wielkoptytowego przez pryzmat rynku nieruchomości [Evaluation of prefabricated blocks of flats through the Real estate market point of view]. Budownictwo i Architektura, 13(3), $57-64$. 